\title{
Automatic On-Line Purge-and-Trap Sequential Injection Analysis for Trace Ammonium Determination in Untreated Estuarine and Seawater Samples
}

\author{
Athina Dimitriadou and Aristidis Anthemidis * \\ Laboratory of Analytical Chemistry, Department of Chemistry, Aristotle University, 54124 Thessaloniki, Greece; \\ athina.dimitriadou@gmail.com \\ * Correspondence: anthemid@chem.auth.gr; Tel.: +30-2310-99-7826
}

Academic Editors: Victoria Samanidou, Eleni Deliyanni and Dimitra Voutsa

Received: 21 February 2020; Accepted: 27 March 2020; Published: 29 March 2020

\begin{abstract}
An innovative automatic purge-and-trap (P\&T) system coupled with fluorimetric sequential injection (SI), for the on-line separation and preconcentration of volatile compounds, is presented. The truth of concept is demonstrated for the ammonium fluorimetric determination in environmental water samples with complex matrices without any pretreatment. The P\&T flow system comprises a thermostated purge-vessel where ammonium is converted into gaseous ammonia and a trap-vessel for ammonia collection. This configuration results in matrix removal as well as analyte preconcentration, avoiding membrane-associated problems. All the main parameters affecting the efficiency of a P\&T system were studied and optimized. The proposed method is characterized by a working range of 2.7-150.0 $\mathrm{g} \mathrm{L} \mathrm{L}^{-1}$ of $\mathrm{NH}_{4}{ }^{+}$, with a detection and quantification limit of 0.80 and $2.66 \mu \mathrm{g} \mathrm{L}^{-1}$, respectively, for a 10-mL sample consumption. The accuracy of the method was assessed by recovery assays in seawater, estuarine, and lake water samples as well as by the analysis of standard reference material.
\end{abstract}

Keywords: automation; purge-and-trap; sequential injection analysis; fluorimetric; ammonium determination; environmental samples

\section{Introduction}

Automatic on-line analytical methods based on flow injection (FIA) and sequential injection (SIA) analysis have been proved to be versatile, fast, accurate, robust, and efficient analytical tools [1]. These methods have led to the development of less invasive chemical assays with low reagent consumption and waste generation, fulfilling the principles of Green Analytical Chemistry (GAC) [2]. A remarkable advantage of automatic on-line systems is their ability to integrate and handle a plethora of sample pretreatment techniques, including sample separation and preconcentration $[3,4]$.

Ammonium is an analyte of high environmental interest due to its double role as a significant ecological nutrient in the nitrogen cycle of seawater and a common pollutant in alkaline aquatic ecosystems. In natural waters, the ratio of ammonia to ammonium is significantly dependent on $\mathrm{pH}$ level and temperature. At alkaline environments, toxic ammonia is the predominant form, which is an indicator of water quality. Various flow-based methods have been implemented for ammonium determination in water samples typically based on the spectrophotometric indophenol blue or fluorimetric o-phthaldialdehyde (OPA) techniques [5]. In particular, the OPA reaction was modified by replacing mercaptoethanol with sulfite, in order to avoid the interference from organic amine compounds resulting in higher sensitivity and selectivity [6]. Afterwards, the method was further modified for the determination of ammonium in seawater [7]. Regarding the direct analysis of ammonium in natural and seawater samples, it suffers from several interferences arising from 
complicated matrices and possible dissolved materials [8]. Hence, separation and preconcentration techniques are required to eliminate matrix problems and to enhance the sensitivity and selectivity of the method.

Several approaches for the on-line ammonia gas-liquid separation have been reported and are classified as: a) membrane-based, such as gas-diffusion (GD) [9-11] and pervaporation [12, 13], b) membranelles-gas-diffusion (MGD) [14-16], and c) headspace single drop (HS-SD)-based techniques $[17,18]$. Membrane-based methods make use of a hydrophobic membrane that allows the diffuse of gaseous ammonia through the membrane, from a donor to an acceptor liquid stream. Nevertheless, serious problems, such as clogging, cracking, and the deterioration of membrane in the GD units, are often observed due to the contact of the membrane with the sample solution. On the other hand, pervaporation units involve an air gap between the membrane and the donor stream in order to overcome the GD limitations. However, reduced diffusion effectiveness has been recorded due to water condensation on the surface of membrane, in pervaporation units $[13,19]$. Regarding both MGD and HS-SD techniques, they require careful and accurate handling of solution, as well as complicated equipment. Lately, a membranelles automated on-line dual-headspace lab-in-syringe (PA-D-HS-LIS) system for the gas separation of volatile compounds was presented for ammonia determination [20]. This system is based on decreased pressure under increased temperature into the headspace of sample solution for effective ammonia gas release. Then, the generated ammonia is transported to the second headspace of the extraction solution for its dissolution under increased pressure.

Purge-and-trap pretreatment is a well-established methodology for separation of volatile organic compounds (VOCs) in aqueous samples with complex matrices. In principle, an inert gas passes through the water to purge the volatile compounds, from the aqueous to gas phase, which are subsequently collected in an appropriate trap for further analysis [21]. Compared to GD and MGD, the P\&T configuration can process higher sample volumes in the pretreatment steps, thus enhanced sensitivity can be achieved [22]. As far as we know, only a few P\&T methods for ammonium determination in a manual operation, have been presented [23,24].

In this study, a novel automatic dynamic purge-and-trap platform based on sequential injection analysis (P\&T-SIA) for the separation and preconcentration of volatile compounds, has been developed for the first time. The proposed system eliminates the serious problems arising from the use of membrane in the GD and pervaporation units. The effectiveness of the P\&T-SIA system was demonstrated for ammonium determination. Gaseous ammonia is generated by adding an appropriate volume of $\mathrm{NaOH}$ solution to the sample. After its transportation, ammonia is dissolved in the acidic trapping solution and is determined by fluorimetric sequential injection analysis (SIA). All the main factors influencing the efficiency of the P\&T system, such as purging flow rate, purging time, temperature, liquid depth, and the concentration of the trapping solution, have been commented and optimized. The applicability of the P\&T-SIA system has been evaluated in seawater, estuarine, and lake water samples for ammonium determination.

\section{Results and Discussion}

\subsection{Optimization of the Automatic Purge-and-Trap System}

The aim of the present study is to develop and evaluate an effective automatic on-line purge-and-trap system, which is able to be connected with the miniSIA device for the fluorimetric determination of ammonium or other volatile compounds. For setting up the P\&T-SIA system, several key issues should be considered. Some of them include the $\mathrm{pH}$, the temperature, and the volume of the sample solution, the flow rate of the purge gas, the time of purging, as well as the type and the volume of trapping solution. 


\subsubsection{Sample Alkalization}

In aqueous solutions, ammonia exists simultaneously as two forms: the free unionized gaseous ammonia $\left(\mathrm{NH}_{3}\right)$ and as the ionized ammonium ion $\left(\mathrm{NH}_{4}{ }^{+}\right)$. Since the $\mathrm{pK}$ a of ammonium ions is 9.26, the $\mathrm{pH}$ value of the sample should be higher than that value to ensure the formation of ammonia is favored. The chemical equilibrium in the water of the two nitrogenous forms (ammonia and ammonium ion) reveals that a $100 \%$ conversion of $\mathrm{NH}_{4}{ }^{+}$to $\mathrm{NH}_{3}(\mathrm{~g})$ requires a $\mathrm{pH}$ value higher than 11.5 at $20^{\circ} \mathrm{C}$. However, higher values than $\mathrm{pH}>13$ are recommended for trace ammonia removal from water due to its high solubility [23,24].

Gaseous $\mathrm{NH}_{3}$ is produced into the purge vessel from the ammonium ion $\mathrm{NH}_{4}{ }^{+}$by sample alkalization with $\mathrm{NaOH}$. Thus, for $10.0 \mathrm{~mL}$ of sample volume, a volume of $1000 \mu \mathrm{L}$ of $1.0 \mathrm{~mol} \mathrm{~L}^{-1}$ $\mathrm{NaOH}$ aqueous solution was employed for ensuring a $\mathrm{pH}$ higher than 13 in the sample solution.

\subsubsection{Trapping Solution}

Ammonium gas dissolution is higher in slightly acidic solution than in double-de-ionized water (DDW), as it is shown from preliminary experiments. On the other hand, when ammonium concentration is at $\mathrm{mg} \mathrm{L}^{-1}$ levels, higher acid concentration is necessary for the best trapping efficiency [25]. Thus, considering the very low concentrations of ammonium (ppb levels) in the samples, the versatility and the requirements of an miniSIA fluorimetric detection system, a $0.001-\mathrm{mol} \mathrm{L}^{-1}$ hydrochloric acid solution was adopted as the trapping solution. It should be mentioned that low volumes of the trapping solution result in a high preconcentration ratio. Thus, for higher sensitivity, a volume of $300 \mu \mathrm{L}$ of $\mathrm{HCl}$ solution into the trap-vessel was used throughout the study.

\subsubsection{Temperature Effect}

Increasing the temperature of the sample solution inside the purge-vessel (PV), causes the decrease of ammonia solubility, as arises from van't Hoff's equation [26]. Raising the temperature increases the kinetic energy of the molecules. Therefore, a higher kinetic energy causes more actuation between the molecules that break the intermolecular bonds and escape from the solution, increasing the generation of the gaseous ammonia [20]. The proposed purge-vessel involves a lab-made heating device to adjust the temperature of the sample solution during purging. The effect of the temperature on the fluorescence intensity has been studied in the range $20-80{ }^{\circ} \mathrm{C}$ and the obtained results are presented in Figure S1 (Supplementary Material). Temperatures above $80^{\circ} \mathrm{C}$ were not applied in order to avoid the possible occurrence of boiling phenomena in the purge vessel and the production of water vapor, which then can be condensate in the tubing and in the trapping vessel. As the recorded signal increased throughout the studied range, for high sensitivity, $80^{\circ} \mathrm{C}$ was adopted for further experiments.

\subsubsection{Sample Volume}

In principle, purging efficiency is affected by several factors, such as Henry's law constant, temperature, the flow rate of the purge gas, purging time, as well as the number and the size of the purge gas bubbles. Another significant parameter is the depth of the solution in the purge vessel, which is proportional to the sample volume. If all other parameters are constant, a higher solution depth results in more bubbles in the liquid phase, increasing the interfacial area and the remaining time of the bubbles in the solution.

In order to estimate the effect of the solution depth on the purging efficiency, five purge-vessels with the same internal diameter (i.d. $=16 \mathrm{~mm}$ ) but at various lengths, were tested. Specifically, for a solution depth between 3.0 and $10.0 \mathrm{~cm}$, an appropriate sample volume was added into the PV, which ranged from 6.0 to $20.0 \mathrm{~mL}$, respectively. Each vessel contained a fixed amount of $5.0 \mu \mathrm{g} \mathrm{NH}_{4}{ }^{+}$. The obtained results are presented in Figure 1, showing that short depth resulted in lower efficiency, as is expected. The optimum depths vary between 4.0 and $7.0 \mathrm{~cm}$. For higher depths, the effectiveness is decreased to some extent, as it is also referred previously [27]. 


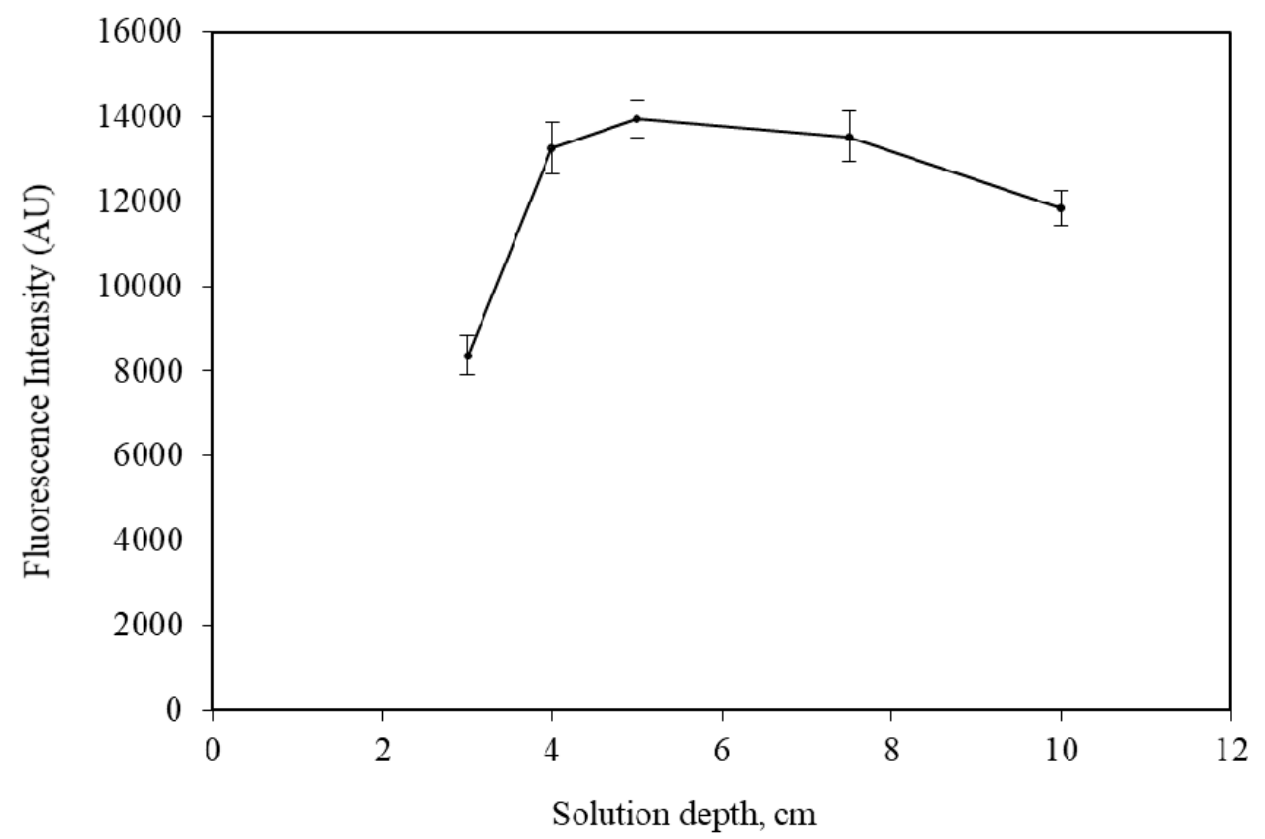

Figure 1. Effect of solution depth in purge-vessel on the intensity of $5.0 \mu \mathrm{g} \mathrm{NH}_{4}{ }^{+}$. The error bars were calculated based on standard deviation $( \pm 1 \mathrm{~s})$. NaOH volume $=1000 \mu \mathrm{L}\left(1.0 \mathrm{~mol} \mathrm{~L}^{-1} \mathrm{NaOH}\right)$; Trapping solution $=300 \mu \mathrm{L}, 0.001 \mathrm{~mol} \mathrm{~L}^{-1} \mathrm{HCl}$; Purge-gas flow rate $=75 \mathrm{~mL} \mathrm{~min}^{-1}$.

\subsubsection{Effect of Purge-Gas Flow Rate and Purging Time}

The effect of the flow rate of the purge-gas on the sensitivity of the method was examined in the range $10-100 \mathrm{~mL} / \mathrm{min}$ and the recorded results presented diagrammatically in Figure S2 (Supplementary Material). As is shown, the intensity increased by increasing the flow rate of argon gas and leveled off for values higher than $75 \mathrm{~mL} / \mathrm{min}$. At flow rates higher than $90 \mathrm{~mL} / \mathrm{min}$, there was a possible transportation of small drops of the liquid through the tubing. Hence, the optimum flow rate of argon gas was set at $75 \mathrm{~mL} / \mathrm{min}$.

Typically, flow analysis methods are not based on thermodynamic equilibrium for their results. In this concept, the purging and trapping operation is not necessary to be completed at the time of measuring. Moreover, the time of purging positively affects the sensitivity of the method and can be considered as preconcentration time. The effect of purging time on sensitivity is shown in Figure S3 (Supplementary Material). It was examined from 1 to $15 \mathrm{~min}$ and it was found that the intensity increased by increasing the purging time, while it was leveled off after $10 \mathrm{~min}$. Consequently, $10 \mathrm{~min}$ was adopted as the optimum purging time.

\subsection{Interferences}

An inherent feature of the purge-and-trap system is the effective separation of volatile compounds, such as ammonia from the matrix of the sample, eliminating the interferences.

Possible gases, such as $\mathrm{CO}_{2}, \mathrm{SO}_{2}$, and $\mathrm{H}_{2} \mathrm{~S}$ are transformed into non-volatile ions $\mathrm{CO}_{3}{ }^{2-}, \mathrm{SO}_{3}{ }^{2-}$ and $\mathrm{HS}^{-}$by alkalization with $\mathrm{NaOH}$. Hence, they remain in the PV and do not interfere. The developed method is possibly affected by metal ions and volatile amines, such as primary amines. The interference studies were performed using a 50.0- $\mathrm{g} \mathrm{L} \mathrm{L}^{-1} \mathrm{NH}_{4}{ }^{+}$standard solution, and a relative deviation of less than $5 \%$ was considered as interference. Commonly encountered matrix components in natural water, such as metal ions $\mathrm{K}^{+}, \mathrm{Na}^{+}, \mathrm{Ca}^{2+}$, and $\mathrm{Mg}^{2+}$, were examined individually for each interferent and found to be tolerated at least up to $500 \mathrm{mg} \mathrm{L}^{-1}$, while $\mathrm{NaCl}$ was tolerated up to $35 \mathrm{~g} \mathrm{~L}^{-1}$. Other metals that could act as interferences are $\mathrm{Zn}^{2+}, \mathrm{Fe}^{3+}, \mathrm{Al}^{3+}, \mathrm{Cu}^{2+}$, and $\mathrm{Ag}^{+}$, which is used as a disinfectant in water recycling systems. No interference was observed for these metals at concentration levels up to $1.0 \mathrm{mg} \mathrm{L}^{-1}$. Primary amine $\left(\mathrm{CH}_{3} \mathrm{NH}_{2}\right)$ can be tolerated at least up to $0.2 \mathrm{mg} \mathrm{L}^{-1}$. 


\subsection{Figures of Merit}

The figures of merit of the proposed method (P\&T-SIA) under the optimum conditions for ammonium determination were calculated as follows. Under the optimum conditions, for a sample volume of $10.0 \mathrm{~mL}$, the working linear range was between 2.7 and $150.0 \mu \mathrm{g} \mathrm{L}^{-1}$ of $\mathrm{NH}_{4}^{+}$with a correlation coefficient $\left(\mathrm{r}^{2}\right)$ of 0.9978 . The calibration curve was characterized by the following regression equation: intensity $=(258.7 \pm 13.8) \times\left[\mathrm{NH}_{4}{ }^{+}\right]+(47.9 \pm 986.4),\left(7\right.$-standards; $n=5 ;\left[\mathrm{NH}_{4}{ }^{+}\right]$ expressed in $\mu \mathrm{g} \mathrm{L}^{-1}$ ). The detection and quantification limits were calculated based on the 3 and $10 \mathrm{~s}$ criterion [28] and found to be 0.80 and $2.66 \mu \mathrm{g} \mathrm{L}^{-1}$, respectively. The precision of the proposed method expressed as relative standard deviation (RSD\%, $n=10$ ), was calculated at 5.0, 20.0, and $100.0 \mu \mathrm{g} \mathrm{L}$ ammonium concentration levels and was found to be $4.8 \%, 4.2 \%$, and $3.7 \%$ respectively. A complete analytical cycle lasts for 900 s, resulting in a sampling frequency $(f)$ of $4 \mathrm{~h}^{-1}$.

For comparative purposes, the performance characteristics of the proposed method and other selected on-line separation methods based on gas diffusion, pervaporation, membranelles-GD, and HS-SD devises, reported in the literature for ammonium determination, are compiled in Table 1. As it is shown herein, the P\&T-SIA method reveals satisfactory sensitivity with better detection limits than earlier works [10,12,15-17,29-31] for ammonium assays. In addition, it should be considered that the proposed system overcomes membrane-related problems and allows for the determination of untreated samples, minimizing the cost of analysis. According to the GAC requirements, the consumption of o-phthaldialdehyde and sodium sulfite is low enough $(\leq 40 \mu \mathrm{L})$ and generated organic waste is limited. Regarding the time of analysis of the proposed methodology is rather higher than the other methods, even though it can be reduced to some extent by a strict synchronization of the analytical steps.

The accuracy of the presented method was estimated using a standard reference material SRM from NIST CertiPUR ${ }^{\circledR} \mathrm{NH}_{4} \mathrm{Cl}$ in $\mathrm{H}_{2} \mathrm{O} 1000 \pm 10 \mathrm{mg} \mathrm{L}^{-1} \mathrm{NH}_{4}{ }^{+}$. After appropriate dilution, the analytical result for ammonium concentration was $935 \pm 42 \mathrm{mg} \mathrm{L}^{-1}$ (standard deviation, $n=3$ ) with a recovery of $93.5 \%$.

The trueness of the P\&T-SIA method was also investigated by analyzing two potable artificial water (PAW) and two hygiene artificial water (HAW) samples, and the obtained results were compared with that obtained by the certified method [32]. The recorded results and the $t_{\text {exp }}$, values are given in Table 2. The overall relative errors were $2.1 \%$ and $3.3 \%$ for PAW and HAW samples, respectively, indicating the efficient applicability of the developed method in similar water samples. Moreover, since all $t_{\exp }$ values are lower than the $t_{\text {crit }}, 95 \%=4.30$, no statistically significant differences were found between the two studied methods. 
Table 1. Comparative figures of merit of the proposed purge-and-trap platform based on sequential injection analysis (P\&T-SIA) method and other on-line separation methods reported in the literature for ammonium determination.

\begin{tabular}{|c|c|c|c|c|c|c|c|c|}
\hline Flow System & $\begin{array}{l}\text { Separation } \\
\text { Technique }\end{array}$ & Detection System & $\begin{array}{l}\text { Linear Range } \\
\left(\mathrm{mg} \mathrm{L}^{-1}\right)\end{array}$ & $\operatorname{LOD}\left(\mu \mathrm{g} \mathrm{L}^{-1}\right)$ & RSD (\%) & $F\left(h^{-1}\right)$ & Sample Type & Ref. \\
\hline MPFS & GD & Chemiluminescence & $0.3-0.5$ & 20 & $<1.2$ & 50 & Tap, river, wastewater & [29] \\
\hline MCFIA & GD & Spectrophotometry/BTB & $0.050-1.0$ & 27 & $<1.5$ & 20 & Surface and tap water & [30] \\
\hline SIA & GD & Spectrophotometry/BTB & $0.10-1.0$ & 27 & $<2$ & 20 & Estuarine, river, well, marine water & [10] \\
\hline FIA & PV & Spectrophotometry/CR - TB & $0.2-20$ & 100 & $<3$ & 11 & Industrial effluents & [12] \\
\hline FIA & PV & Spectrophotometry/BTB & $0.05-50$ & 30 & 1.9 & $10 / 8$ & Surface, urban sewage, industrial effluents & [31] \\
\hline LIS & HS-SDME & Spectrophotometry/BTB & up to 0.425 & 30 & $<8$ & 17 & River, coastal seawater & [17] \\
\hline MSFIA & MGD & Spectrophotometry/BTB & $10.0-50.0$ & 2200 & 4.8 & 11 & River, wastewater & [15] \\
\hline SIA & MBL-VP & Conductivity & $0.09-1.44$ & 36 & 2.0 & 12 & Canal water & [16] \\
\hline LIS-SIA & PA-D-HS & Fluorimetry & $0.15-10.0 *$ & 0.05 & 3.6 & 8 & Seawater, river, lake, ditch water & [20] \\
\hline FIA & P\&T (off-line) & Fluorimetry & $0.18-7.2 *$ & 0.13 & 4.4 & 4 & Seawater & [24] \\
\hline SIA & P\&T & Fluorimetry & $2.66-150 *$ & 0.80 & 4.2 & 4 & Estuarine, lake, seawater & $* *$ \\
\hline
\end{tabular}

* expressed as $\mu \mathrm{g} \mathrm{L}{ }^{-1}$;** present work; HS-SDME, headspace-single-drop microextraction; MBL-VP, membranelles-vaporization; MCFIA, multi-commuted FIA; MGD, membranelles gas-diffusion; MPFS, multi-pumping flow system; MSFIA, multisyringe FIA; PA-D-HS, pressure-assisted-dual-headspace; P\&T, purge-and-trap; PV, pervaporation; BTB, bromothymol blue; $C R$, cresol red; TB, thymol blue; $f$, sampling frequency; LOD, limit of detection. 
Table 2. Analytical results obtained by the P\&T-SIA method and by the certified method for the determination of ammonium in potable (PAW) and hygiene (HAW) artificial water samples.

\begin{tabular}{|c|c|c|c|c|c|}
\hline Sample & $\begin{array}{l}\text { True Value } \\
\left(\mu \mathrm{g} \mathrm{L}^{-1}\right)\end{array}$ & $\begin{array}{l}\text { Certified Method * } \\
\qquad\left(\mu \mathrm{g} \mathrm{L}^{-1}\right)\end{array}$ & $\begin{array}{l}\text { P\&T-SIA Method * } \\
\qquad\left(\mu \mathrm{g} \mathrm{L}^{-1}\right)\end{array}$ & $\begin{array}{c}\text { Relative Error } \\
(\%)\end{array}$ & $t_{\exp }$ \\
\hline PWA-1 & 25.0 & $24.2 \pm 1.8$ & $23.8 \pm 1.5$ & 1.7 & 0.831 \\
\hline PWA-2 & 50.0 & $48.0 \pm 3.2$ & $46.8 \pm 2.5$ & 2.5 & 0.462 \\
\hline \multicolumn{4}{|c|}{ Overall relative error } & 2.1 & \\
\hline HWA-1 & 50.0 & $51.6 \pm 4.3$ & $48.8 \pm 2.4$ & 5.4 & 2.021 \\
\hline HWA-2 & 100.0 & $97.8 \pm 8.6$ & $96.6 \pm 5.2$ & 1.2 & 0.400 \\
\hline \multicolumn{4}{|c|}{ Overall relative error } & 3.3 & \\
\hline
\end{tabular}

${ }^{*}$ Mean value \pm standard deviation $(n=3)$.

\subsection{Applications in Spiked Environmental Water Samples}

The proposed method has been applied to the analysis of collected (March 2019) environmental water samples namely estuarine, lake, and seawater. The recovery $(R)$ values were estimated by analyzing the spiked samples with $20.0 \mathrm{\mu g} \mathrm{L}^{-1} \mathrm{NH}_{4}{ }^{+}$concentration level. The recorded results are presented in Table 3. The recoveries varied within the range $94.0 \%-102.0 \%$, showing the applicability of the developed method for ammonium determination in natural water samples, even in samples with high salinity such as seawaters.

Table 3. Application of the proposed P\&T-SIA method for ammonium determination in spiked natural water samples.

\begin{tabular}{|c|c|c|c|}
\hline Sample Type & $\begin{array}{l}\text { Added * } \\
\left(\mu g L^{-1}\right)\end{array}$ & $\begin{array}{l}\text { Found * } \\
\left(\mu \mathrm{g} \mathrm{L}^{-1}\right)\end{array}$ & $R(\%)$ \\
\hline \multirow[t]{3}{*}{ Strymon estuarine water } & & N.D. & \\
\hline & 20.0 & $19.2 \pm 0.9$ & 96.0 \\
\hline & 50.0 & $48.8 \pm 1.5$ & 97.6 \\
\hline \multirow[t]{3}{*}{ Prespa lake water } & & $35.2 \pm 2.2$ & \\
\hline & 20.0 & $54.7 \pm 2.7$ & 97.5 \\
\hline & 50.0 & $86.2 \pm 2.8$ & 102.0 \\
\hline \multirow[t]{3}{*}{ Thermaikos gulf seawater } & & $12.5 \pm 0.5$ & \\
\hline & 20.0 & $31.3 \pm 1.8$ & 94.0 \\
\hline & 50.0 & $60.2 \pm 2.8$ & 95.4 \\
\hline \multirow[t]{3}{*}{ Toroneos gulf seawater } & & N.D. & \\
\hline & 20.0 & $20.3 \pm 1.3$ & 101.5 \\
\hline & 50.0 & $47.3 \pm 2.8$ & 94.6 \\
\hline
\end{tabular}

${ }^{*}$ Mean value \pm standard deviation; N.D, not detected.

\section{Materials and Methods}

\subsection{The Automatic Purge-and-Trap Platform}

The developed purge-and-trap (P\&T-SIA) system for ammonium separation/preconcentration and determination is presented schematically in Figure 2. It consists of a high precision bi-directional micro-syringe pump, SP2 (MicroCSP-3000, FIAlab Instruments, Bellevue, WA, USA), which is equipped with a 5000- $\mu \mathrm{L}$ glass barrel and a nine-position Teflon/Kel-F SV2 selection valve, directly connected at the top of the barrel. The purge-vessel (PV) is made of a borosilicate glass tubing (1.6 mm i.d., $100 \mathrm{~mm}$ length) with two push-fit poly tetra fluoro ethylene (PTFE) connectors at its two ends, as is shown in Figure 3. The lower connector is a male flangeless fitting end in order to be connected at the port- 5 of SV2 (Figure 1). This connector enables the insertion of the purge gas at the bottom of the PV by four tiny holes, which are connected with a purge gas tubing. The PV is placed in a vertical position in the P\&T manifold. 


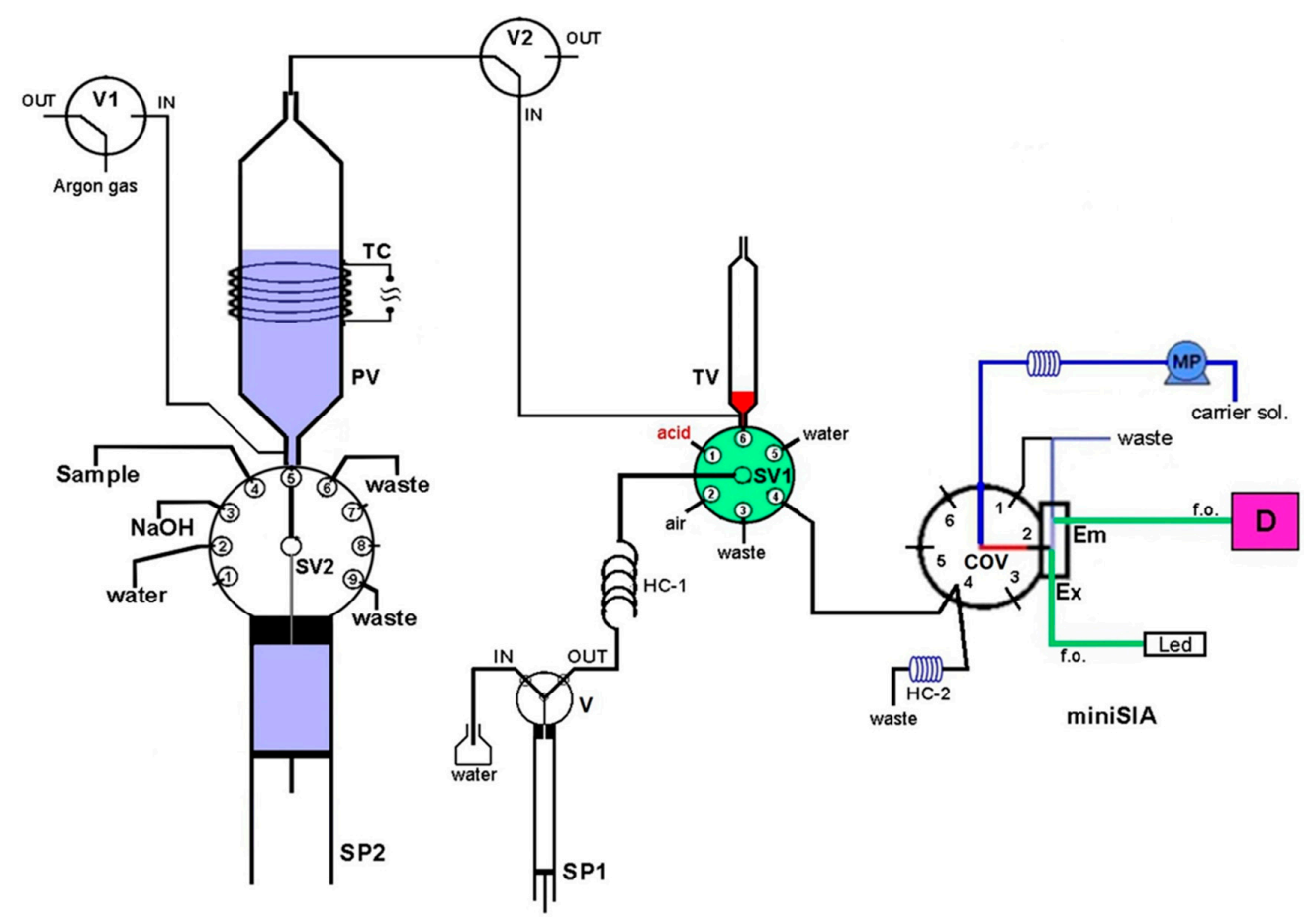

Figure 2. Schematic diagram of the P\&T-SIA manifold for ammonium determination. PV, purge vessel; $\mathrm{TV}$, trap vessel; SV1 and SV2, selection valves; COV, chem-on-valve unit with the flow-through cell; V, V1, V2, valves; SP1, SP2, syringe pumps; TC, thermostated coil; HC-1, HC-2, holding coils; MP, milliGUT pump; f.o., fiber optics; D, detector.

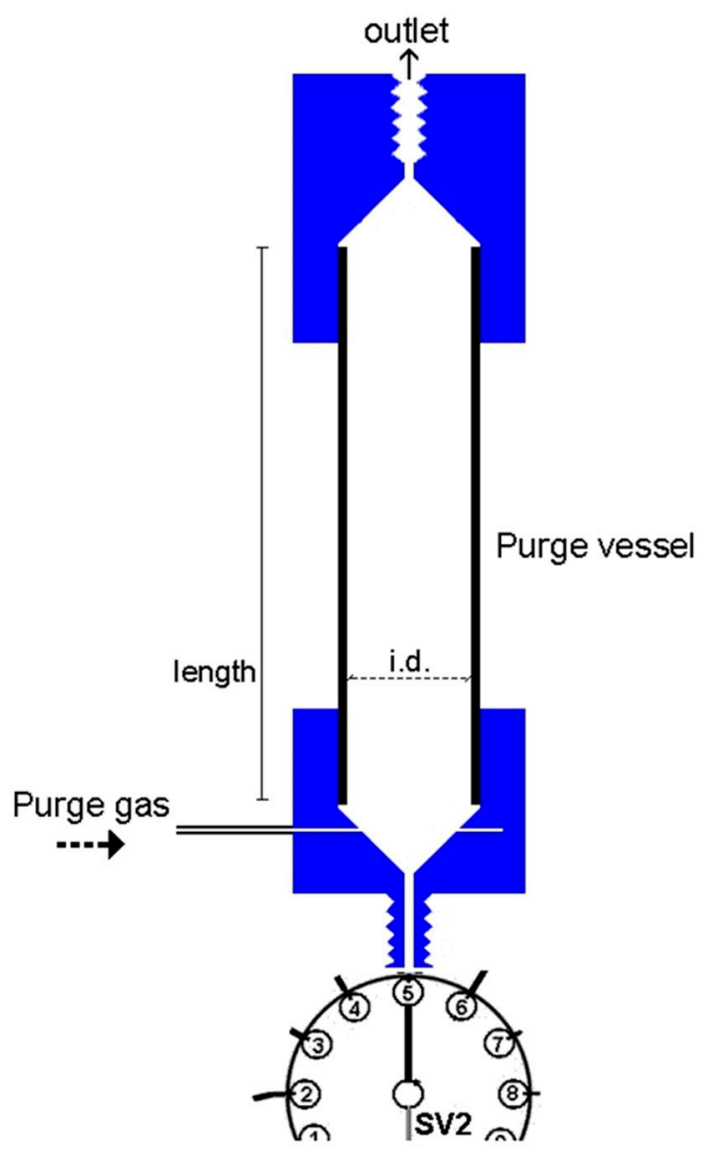

Figure 3. Schematic diagram of the purge-vessel. Internal diameter, i.d. $=1.6 \mathrm{~mm}$; length $=100 \mathrm{~mm}$. 
In order to facilitate the gaseous ammonia release, the PV is heated at the appropriate temperature by a lab-made heating device, which consists of a thermostat and a chromium-nickel resistor coil (TC), electrically powered with a $12 \mathrm{~V} / 5 \mathrm{~A}$ power supply. The trap-vessel (TV) is made of a plastic syringe (4.6 mm i.d., $70 \mathrm{~mm}$ length), located in the P\&T manifold in a vertical position, by using a push-fit connector with a male fitting end. The TV is connected at the SV1 (port-6) of the FIAlab-3000 ${ }^{\circledR}$ SI system.

\subsection{Apparatus}

A FIAlab ${ }^{\circledR}-3000$ sequential injection (SI) system (Alitea FIAlab, Bellevue, WA, USA) was used for the handling of the P\&T system. This system is equipped with a syringe pump, SP1 (Cavro, Sunnyvale, CA, USA) with a glass syringe barrel of $1000 \mu \mathrm{L}$ capacity and a two-position (IN/OUT) valve (V), a six-port selection valve (SV1) and a holding coil (HC-1). Two additional three-port, two-position valves, V1 and V2 controlled by the FIAlab ${ }^{\circledR}-3000$ SI system, were used for the purge gas handling. The Micro CSP-3000 syringe pump is interfaced with the FIAlab ${ }^{\circledR}-3000$ system and controlled by a personal computer that runs the FIAlab software for windows v. 5.9.245 (http://www.flowinjection.com).

A miniSIA flow analyzer (https://www.globalfia.com) equipped with an acrylic Chem-on-Valve ${ }^{\mathrm{TM}}$ (COV) monolithic manifold was employed for ammonium SI fluorimetric determination. The miniSIA flow analyzer is equipped with a fluorescence flow cell which is located directly in the COV at position-2 (Figure 2). Two fiber optic cables (f.o.) are used for light emission (Em) and excitation (Ex). For the fluorometric detection of ammonium, an Ocean-Optics USB-4000 fluorescence spectrometer with a monochromator set at $425 \mathrm{~nm}$ emission wavelength, is used. In addition, a monochrome white LED is used as an excitation light source and has been set at $365 \mathrm{~nm}$ excitation wavelength. The recorded fluorescence intensity is given as intensity arbitrary units (AU). More details of the miniSIA flow analyzer are presented in previous work [33]. The quantification of ammonium in miniSIA flow analyzer is based on the OPA reaction, where the ammonia reacts with o-phthaldialdehyde in the presence of a strong reducing agent, sulfite, in order to produce the fluorescent isoindole derivative. The reaction is time and temperature depended.

For the control of miniSIA system and the data acquisition, a laptop running the FloZF 5.2 software (https://www.globalfia.com), is used. The integrated P\&T-SIA system is controlled by the two discrete software programs namely FIAlab and FloZF, which are synchronized and activated simultaneously.

\subsection{Chemicals and Samples}

Analytical-grade chemicals were provided by Merck (Darmstadt, Germany, http://www.merck.de) and were used throughout the study. A Milli-Q system (Millipore, Bedford, MA, USA, http://www. millipore.com) was employed for ultra-pure quality water. All ammonium working standard solutions were prepared daily by the appropriate dilution of $5000 \mathrm{mg} \mathrm{L}^{-1}$ of $\mathrm{NH}_{4}^{+}$stock standard solution with water. A phosphate buffer at $0.1 \mathrm{~mol} \mathrm{~L}^{-1}$ concentration level was prepared by dissolving $13.4 \mathrm{~g} \mathrm{Na}_{2} \mathrm{HPO}_{4}$ in $400 \mathrm{~mL}$ of water, adjusting the $\mathrm{pH}$ to 11.0 with $2.0 \mathrm{~mol} \mathrm{~L}^{-1} \mathrm{NaOH}$ solution and diluting into a $500-\mathrm{mL}$ volumetric flask. A solution of $6.0 \mathrm{mmol} \mathrm{L}^{-1}$ sodium sulfite was prepared by dissolving $75.6 \mathrm{mg}$ of $\mathrm{Na}_{2} \mathrm{SO}_{3}(\mathrm{~s})$ in phosphate buffer and diluting to $100 \mathrm{~mL}$. A solution of $15.0 \mathrm{mmol}$ $\mathrm{L}^{-1}$ o-phthaldialdehyde (OPA) was prepared by dissolving $201.0 \mathrm{mg}$ of solid $\mathrm{C}_{8} \mathrm{H}_{6} \mathrm{O}_{2}$ in $20.0 \mathrm{~mL}$ methanol and diluting to $100.0 \mathrm{~mL}$ with water. Argon (99.997\%, Grade 4.7$)$ was used as a purge gas for triggering the release of the ammonia gas from the liquid mixture and transportation to the trap vessel. For ammonium determination by the certified method [32], the following solutions have been prepared properly: a $5 \% \mathrm{~m} / \mathrm{v}$ sodium hypochlorite solution $(\mathrm{NaClO}) ;$ a $11.1 \%(v / v)$ phenol $\left(\mathrm{C}_{6} \mathrm{H}_{6} \mathrm{O}\right)$ solution in ethanol; a $20 \%(\mathrm{~m} / \mathrm{v})$ alkaline citrate solution; a $0.5 \%(\mathrm{~m} / \mathrm{v})$ sodium nitroprusside $\left(\mathrm{Na}_{2} \mathrm{Fe}(\mathrm{CN})_{5} \mathrm{NO}\right)$ aqueous solution; and a $1 \%(\mathrm{~m} / \mathrm{v}) \mathrm{NaClO}$ in $16 \% \mathrm{~m} / \mathrm{v}$ citrates solution.

For the accuracy validation of the developed method, an ammonium standard reference solution traceable to SRM from the NIST (National Institute of Standard and Technology, Gaithersburg, MD, USA) $\mathrm{NH}_{4} \mathrm{Cl}$ in $\mathrm{H}_{2} \mathrm{O} 1000 \mathrm{mg} \mathrm{L}^{-1} \mathrm{NH}_{4}{ }^{+}$CertiPUR ${ }^{\circledR}$ has been analyzed, after dilution. Two potable 
artificial water samples (PAW) and two hygiene artificial water samples (HAW), at 25.0/50.0 $\mathrm{g} \mathrm{L} \mathrm{L}^{-1}$ and at 50.0/100.0 $\mu \mathrm{g} \mathrm{L}-1$ concentration levels of $\mathrm{NH}_{4}{ }^{+}$, respectively, were prepared according to the chemical composition of the recycled water in the International Space Station (ISS). The chemical constitution of them is given elsewhere [33].

The environmental water samples were collected from sampling sites that are located in northern Greece, during March 2019. The estuarine water was from the Strymon river, the lake water was from lake Prespa, and the seawater was from the Thermaikos gulf (Thessaloniki) and the Toroneos gulf (Chalkidiki). The collected samples were filtered through $0.45-\mu \mathrm{m}$ membrane filter, acidified to ca. $\mathrm{pH}$ 2.0 with dilute nitric acid, and stored at $4{ }^{\circ} \mathrm{C}$ in acid-cleaned polyethylene bottles prior to analysis. The laboratory glassware was rinsed with water after decontaminated overnight in a $10 \%(v / v)$ nitric acid solution.

\subsection{On-Line Analytical Procedure}

The schematic diagram of the on-line P\&T-SIA system for the fluorimetric determination of ammonium is given in Figure 2, while the operational sequence of the proposed method is summarized in Table 4.

At the start-up of the system, the argon purge gas flows through the PV and TV (V1 and V2 in IN position), while the thermostated heater is activated, in order to remove possible ammonia gas molecules from the two vessels. In steps $1-2,300 \mu \mathrm{L}$ of trapping solution $\left(0.001 \mathrm{~mol} \mathrm{~L}^{-1} \mathrm{HCl}\right)$ is delivered into the trap vessel, while V1 and V2 are in the "OUT" and "IN" position, respectively. Next (steps 4-7), appropriate volumes of 1.0-mol L ${ }^{-1} \mathrm{NaOH}$ and sample/standard solutions are sequentially loaded into the PV by the operation of SP2 through ports 3 and 4 of SV2, respectively. The presence of $\mathrm{NaOH}$ creates an alkaline environment inside PV which results in the conversion of ammonium ion to ammonia (gas). Then, the operation of Purge-and-Trap starts (step 10). Specifically, the argon purge gas is flowing in the PV through the sample solution in the PV by switching the V1 in the "IN" position, for a purging time of $600 \mathrm{~s}$. During this step, the sample solution is heated into PV at $80^{\circ} \mathrm{C}$. Consequently, ammonia-gas is released and transported by the argon gas into the TV in order to be dissoluted in the $\mathrm{HCl}$ solution (trapping solution).

In the following steps (11-13), the trapping solution is delivered and "parked" in the holding coil HC-2, by the operation of SP1. Then, a small segment of $40 \mu \mathrm{L}$ is aspirated through port 4 of the COV, into miniSIA analyzer for fluorimetric quantification. The determination of ammonia is based on its reaction with o-phthaldialdehyde (OPA) and sodium sulfite, resulting in the formation of the isoindole derivative. The reaction is depended from the time and temperature. The operational protocol of the miniSIA system, the optimization procedure, as well as all performance characteristics have been presented in detail in our previous work [33]. In the last steps (14-29), a thorough cleaning of the system, including the purge-and-trap vessels and the entire tubing, is performed using ultra-pure water to eliminate any possible carryover phenomenon. Five replicate measurements have been made in all instances. 
Table 4. Operational sequences of the P\&T-SIA system for ammonia preconcentration and determination.

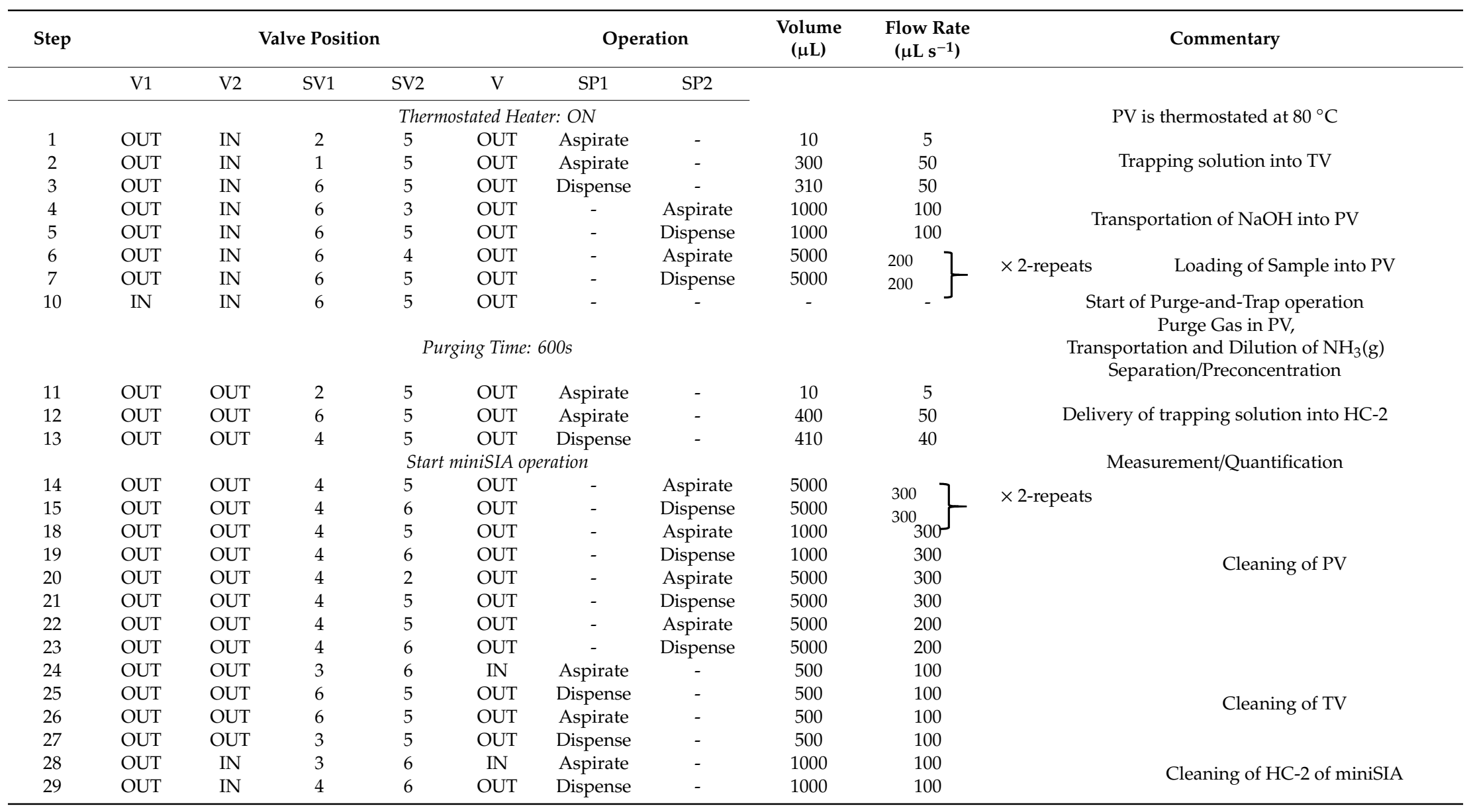




\section{Conclusions}

An automatic thermostated on-line purge-and-trap system based on the instrumentation of sequential injection analysis was developed for volatile compounds for the first time. The efficiency of the proposed P\&T-SIA system coupled to a miniSIA flow analyzer has been successfully demonstrated for direct ammonium separation, preconcentration, and determination in environmental water samples. The presented flow method combines the advantages of membraneless purge-and-trap pretreatment and sequential injection systems. The simplicity, versatility, ease, and low costs of the operation are some distinct advantages that the P\&T-SIA flow manifold exhibits. According to the obtained results for ammonium determination, it can be concluded that the newly developed method offers remarkable analytical features, such as good accuracy and reproducibility as well as high sensitivity. The applicability was examined in environmental water samples and specifically in seawater samples. The fluorimetric detection method is regarded as a green and environmentally friendly approach, minimizing the use of toxic reagents in $\mu \mathrm{L}$ levels and generating limited wastes. All these characteristics make the proposed P\&T-SIA platform an attractive new tool for determining trace amounts of volatile compounds, suitable for monitoring water pollution.

Supplementary Materials: The following are available online: Figure S1: Effect of the temperature on the fluorescence intensity of $50.0 \mu \mathrm{g} \mathrm{L}^{-1} \mathrm{NH}_{4}{ }^{+}$. Error bars were calculated based on standard deviation $( \pm 1 \mathrm{~s})$. Sample volume $=10.0 \mathrm{~mL} ; \mathrm{NaOH}$ volume $=1000 \mu \mathrm{L}$ of $1.0 \mathrm{~mol} \mathrm{~L}^{-1} \mathrm{NaOH}$; Trapping solution: $300 \mu \mathrm{L}, 0.001 \mathrm{~mol} \mathrm{~L}^{-1} \mathrm{HCl}$; Purge-gas flow rate $=75 \mathrm{~mL} \mathrm{~min}^{-1}$, Figure S2: Effect of purge-gas flow rate of the on the sensitivity of the method. Error bars were calculated based on standard deviation $( \pm 1 s)$. Other parameters as in Figure S1, Figure S3: Effect of purging time on the fluorescence intensity of $50.0 \mathrm{\mu g} \mathrm{L}^{-1} \mathrm{NH}_{4}{ }^{+}$. Error bars were calculated based on standard deviation $( \pm 1 s)$. All other parameters as in Figure S1.

Author Contributions: Conceptualization, A.A. and A.D.; Data curation and A.A.; Investigation, A.D.; Supervision, A.A.; Validation, A.D.; Writing—original draft, A.D.; Writing—review \& editing A.A. All authors have read and agreed to the published version of the manuscript.

Funding: This research received no external funding.

Conflicts of Interest: The authors declare no conflict of interest.

\section{References}

1. Clavijo, S.; Avivar, J.; Suárez, R.; Cerdà, V. Analytical strategies for coupling separation and flow-injection techniques. Trends Anal. Chem. 2015, 67, 26-33. [CrossRef]

2. Melchert, W.R.; Reis, B.F.; Rocha, F.R.P. Green chemistry and the evolution of flow analysis. A review. Anal. Chim. Acta 2012, 714, 8-19. [CrossRef] [PubMed]

3. Miró, M.; Hansen, E.H. On-line sample processing involving microextraction techniques as a front-end to atomic spectrometric detection for trace metal assays: A review. Anal. Chim. Acta 2013, 782, 1-11. [CrossRef] [PubMed]

4. Trojanowicz, M.; Kołacińska, K. Recent advances in flow injection analysis. Analyst 2016, 14, 2085-2139. [CrossRef] [PubMed]

5. O'Connor Šraj, L.; Almeida, M.I.G.S.; Swearer, S.E.; Kolev, S.D.; McKelvie, I.D. Analytical challenges and advantages of using flow-based methodologies for ammonia determination in estuarine and marine waters. Trends Anal. Chem. 2014, 59, 83-92. [CrossRef]

6. Genfa, Z.; Dasgupta, P.K. Fluorometric measurement of aqueous ammonium ion in a flow injection system. Anal. Chem. 1989, 61, 408-412. [CrossRef]

7. Kerouel, R.; Aminot, A. Fluorometric determination of ammonia in sea and estuarine waters by direct segmented flow analysis. Mar. Chem. 1997, 57, 265-275. [CrossRef]

8. Lin, K.; Zhu, Y.; Zhang, Y.; Lin, H. Determination of ammonia nitrogen in natural waters: Recent advances and applications. Trends Environ. Anal. Chem. 2019, 24, e00073. [CrossRef]

9. Kolev, S.D.; Fernandes, P.R.L.V.; Satinsky, D.; Solich, P. Highly sensitive gas-diffusion sequential injection analysis based on flow manipulation. Talanta 2009, 79, 1021-1025. [CrossRef] 
10. Segundo, R.A.; Mesquita, R.B.R.; Ferreira, M.T.S.O.B.; Teixeira, C.F.C.P.; Bordalo, A.A.; Rangel, A.O.S.S. Development of a sequential injection gas diffusion system for the determination of ammonium in transitional and coastal waters. Anal. Methods 2011, 3, 2049-2055. [CrossRef]

11. Timofeeva, I.I.; Bulatov, A.V.; Moskvin, A.L.; Kolev, S.D. A gas-diffusion flow injection method coupled with online solid-liquid extraction for the determination of ammonium in solid samples. Talanta 2015, 142, 140-144. [CrossRef] [PubMed]

12. Wang, L.; Cardwell, T.J.; Cattrall, R.W.; Luque de Castro, M.D.; Kolev, S.D. Pervaporation-flow injection determination of ammonia in the presence of surfactants. Anal. Chim. Acta 2000, 416, 177-184. [CrossRef]

13. Wang, L.; Cardwell, T.J.; Cattrall, R.W.; Luque de Castro, M.D.; Kolev, S.D. Determination of ammonia in beers by pervaporation flow injection analysis and spectrophotometric detection. Talanta 2003, 60, 1269-1275. [CrossRef]

14. Mornane, P.; van den Haaka, J.; Cardwell, T.J.; Cattrall, R.W.; Dasgupta, P.K.; Kolev, S.D. Thin layer distillation for matrix isolation in flow analysis. Talanta 2007, 72, 741-746. [CrossRef]

15. Almeida, M.I.G.S.; Estela, J.M.; Segundo, M.A.; Cerdà, V. A membraneless gas-diffusion unit - multisyringe flow injection spectrophotometric method for ammonium determination in untreated environmental samples. Talanta 2011, 84, 1244-1252. [CrossRef]

16. Alahmad, W.; Pluangklang, T.; Mantim, T.; Cerdà, V.; Wilairat, P.; Ratanawimarnwong, N.; Nacapricha, D. Development of flow systems incorporating membraneless vaporization units and flow-through contactless conductivity detector for determination of dissolved ammonium and sulfide in canal water. Talanta 2018, 177, 34-40. [CrossRef]

17. Sramkova, I.; Horstkotte, B.; Sklenarova, H.; Solich, P.; Kolev, S.D. A novel approach to lab-in-syringe head-space single-drop microextraction and on-drop sensing of ammonia. Anal. Chim. Acta 2016, 934, 132-144. [CrossRef]

18. Timofeeva, I.; Khubaibullin, I.; Kamencev, M.; Moskvin, A.; Bulatov, A. Automated procedure for determination of ammonia in concrete with headspace single-drop micro-extraction by stepwise injection spectrophotometric analysis. Talanta 2015, 133, 34-37. [CrossRef]

19. Luque de Castro, M.D.; Gamiz-Gracia, L. Analytical pervaporation: An advantageous alternative to headspace and purge-and-trap techniques. Chromatographia 2000, 52, 265-272. [CrossRef]

20. Giakisikli, G.; Anthemidis, A.N. Automatic pressure-assisted dual-headspace gas-liquid microextraction. Lab-in-syringe platform for membraneless gas separation of ammonia coupled with fluorimetric sequential injection analysis. Anal. Chim. Acta 2018, 1033, 73-80. [CrossRef]

21. Martínez, E.; Lacorte, S.; Llobeta, I.; Viana, P.; Barceló, D. Multicomponent analysis of volatile organic compounds in water by automated purge and trap coupled to gas chromatography-mass spectrometry. J. Chromatogr. A 2002, 959, 181-190. [CrossRef]

22. Zhu, Y.; Chen, J.; Yuan, D.; Yang, Z.; Shi, X.; Li, H.; Jin, H.; Ran, L. Development of analytical methods for ammonium determination in seawater over the last two decades. Trends Anal. Chem. 2019, 119, 115627. [CrossRef]

23. Wang, P.-Y.; Wu, J.-Y.; Chen, H.-J.; Lin, T.-Y.; Wu, C.-H. Purge-and-trap ion chromatography for the determination of trace ammonium ion in high-salinity water samples. J. Chromatogr. A 2008, 1188, 69-74. [CrossRef] [PubMed]

24. Zhu, Y.; Yuan, D.; Lin, H.; Zhou, T. Determination of ammonium in seawater by purge-and-trap and flow injection with fluorescence detection. Anal. Lett. 2016, 49, 665-675. [CrossRef]

25. Lin, T.-Y.; Pan, Y.-T.; Lee, H.-Y.; Wang, P.-Y.; Wu, C.-H. Markedly enhanced purge-and-trap performance and efficiency for the determination of ammonium ion in high-salinity water samples. J. Chin. Chem. Soc. 2012, 59, 718-726. [CrossRef]

26. Sander, R. Compilation of Henry's law constants (version 4.0) for water as solvent. Atmos. Chem. Phys. 2015, 15, 4399-4981. [CrossRef]

27. Saridara, C.; Brukh, R.; Mitra, S. Development of continuous on-line purge and trap analysis. J. Sep. Sci. 2006, 29, 446-452. [CrossRef]

28. Inczedy, J.; Lengyel, T.; Ure, A.M. International Union of Pure and Applied Chemistry, Compendium of Analytical Nomenclature (definitive rules 1997), 3rd ed.; Blackwell Science: Oxford, UK, 1998. 
29. Marques, K.L.; Pires, C.K.; Santos, J.L.M.; Zagatto, E.A.G.; Lima, J.L.F.C. A multi-pumping flow system for chemiluminescent determination of ammonium in natural waters. Int. J. Environ. Anal. Chem. 2007, 87, 77-85. [CrossRef]

30. Oliveira, S.M.; Lopes, T.I.M.S.; Tóth, I.V.; Rangel, A.O.S.S. A multi-commuted flow injection system with a multi-channel propulsion unit placed before detection: Spectrophotometric determination of ammonium. Anal. Chim. Acta 2007, 600, 29-34. [CrossRef]

31. Hong, L.; Sun, X.; Wang, L. Determination of ammonia in water using flow injection analysis with automatic pervaporation enrichment. Anal. Lett. 2009, 42, 2364-2377. [CrossRef]

32. Federation, Water Environmental, and American Public Health Association. Standard Methods for the Examination of Water and Wastewater; American Public Health Association (APHA): Washington, DC, USA, 1999.

33. Giakisikli, G.; Trikas, E.; Petala, M.; Karapantsios, T.; Zachariadis, G.; Anthemidis, A. An integrated sequential injection analysis system for ammonium determination in recycled hygiene and potable water samples for future use in manned space missions. Microchem. J. 2017, 133, 490-495. [CrossRef]

Sample Availability: Samples of the compounds are not available from the authors.

(C) 2020 by the authors. Licensee MDPI, Basel, Switzerland. This article is an open access article distributed under the terms and conditions of the Creative Commons Attribution (CC BY) license (http://creativecommons.org/licenses/by/4.0/). 